JEL Classification:

DOI: https://doi.org/10.46361/2449-2604.8.3.2021.52-63

\section{VOLODYMYR SHALIMOV}

PhD in Economics, Associate professor of Department of Finance,

Banking and Insurance

Central Ukrainian National Technical

University, Kropyvnytskyi, Ukraine

ORCID ID https://orcid.org/0000-0001-

9462-8277

E-mail: v.shalimov@ukr.net

\section{TATIANA MELNYK}

PhD in Economics, Associate professor of Department of Finance,

Banking and Insurance

Central Ukrainian National Technical

University, Kropyvnytskyi, Ukraine

ORCID ID https://orcid.org/0000-0003-

1372-3585

e-mail: semenovichta@ukr.net

\section{VALERII RESHETOV}

PhD in Economics, Associate professor of Department of Audit, Accounting and Taxation Central Ukrainian National Technical University, Kropyvnytskyi, Ukraine

ORCID ID https://orcid.org/0000-00019664-4764

e-mail: reshetov.audit@gmail.com

\section{Edited by:}

November, 2021

Reviewed by:

December, 2021

(C) Innovative Economics and Management, 2021

\section{PRINCIPLES OF TAXATION AND BUDGET POLICY: THE NECESSITY OF THE STIMULATION OF THE ECONOMIC AND INNOVATIVE DEVELOPMENT}

The purpose of the study is to analyse the current practice of taking into account the goals of socio-economic and, first of all, innovative development in the principles of the budget and tax systems of Ukraine and substantiation of approaches to its improvement.

It is substantiated that goals of socio-economic and innovative development is not properly reflected in the principles of both the budget system of Ukraine and in the principles of the tax system (basic principles of tax legislation). It is determined that direct and indirect state financial support and taxes as fiscal instruments should help stimulate economic development, stimulate and intensify innovation, but the choice of forms and methods of such stimulation needs to be justified taking into account the need to achieve specific goals. An analysis of the practices of the World Tax Code and the world practice of applying measures to support small and medium enterprises in terms of Covid-19 showed that direct state financial support is preferred in comparison with tax benefits due to clearer procedures of administration and control and further stimulation of development. It is proved that the combination of direct financial support with the using of investment and innovation tax credits with the possibility of their clear tax administration and control is the optimal mechanism in modern conditions.

The directions of reforming the system of local taxation in the context of stimulating socio-economic and innovative development in the region are offered. The need to expand the powers of local governments, local authorities and local communities to establish elements of local taxes and fees, develop a mechanism for investment and innovation tax credits and other types of tax benefits that would enhance innovation in the region are substantiated.

Key words. Innovative development, socio-economic development, budget system, taxation, tax system, principles 
ISSN 2449-2604

JEL Classification:

DOI: https://doi.org/10.46361/2449-2604.8.3.2021.52-63

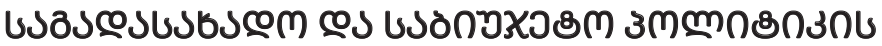

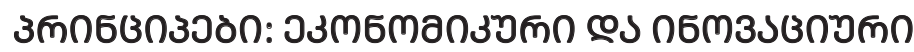

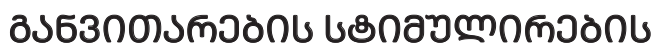 sगзกмJodmmos}

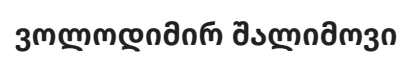

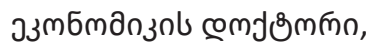

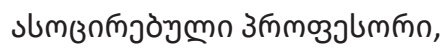

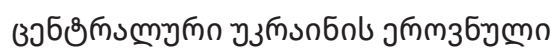

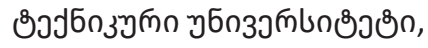

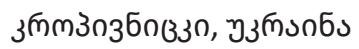
ORCID ID https://orcid.org/0000-00019462-8277

E-mail: v.shalimov@ukr.net

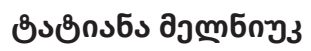

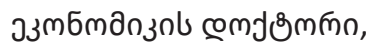

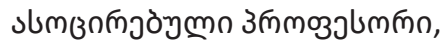

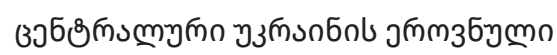

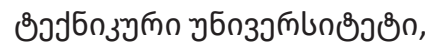

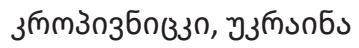
ORCID ID https://orcid.org/0000-00031372-3585

e-mail: semenovichta@ukr.net

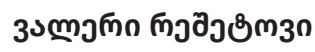

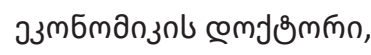

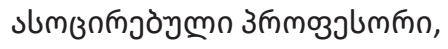

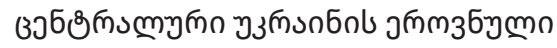

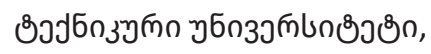

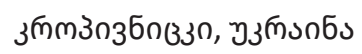
ORCID ID https://orcid.org/0000-00019664-4764

e-mail: reshetov.audit@gmail.com

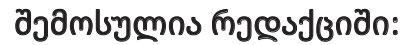

Бмэวฎว๓о, 2021

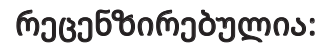

œวзวдљюо, 2021

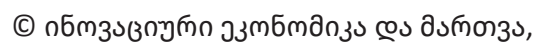
2021

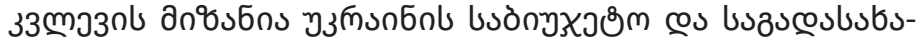

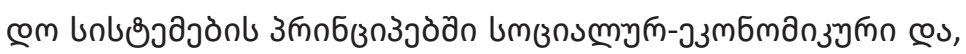

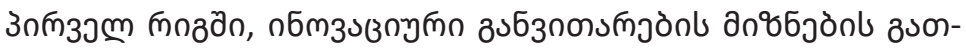

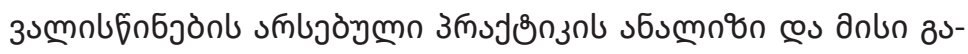

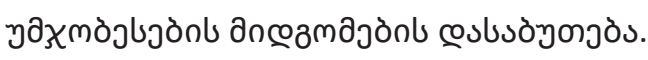

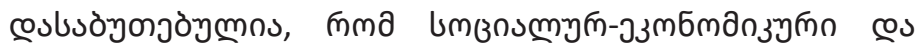

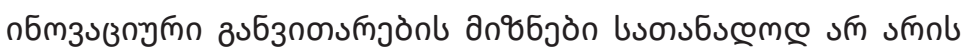

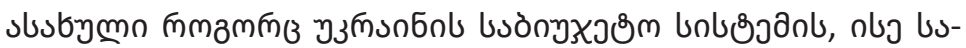

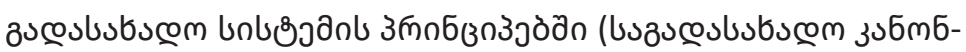

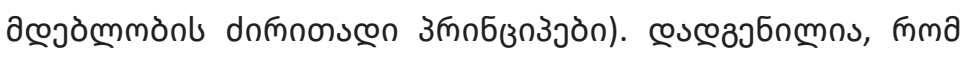

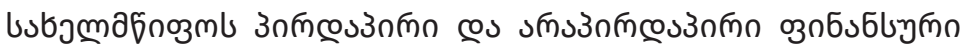

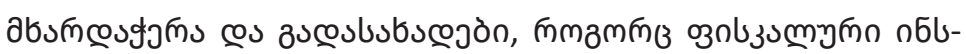

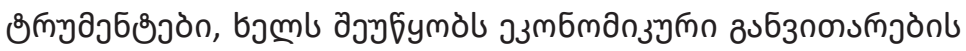

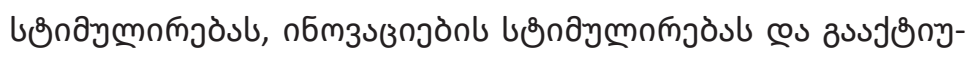

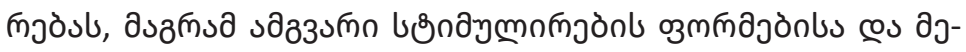

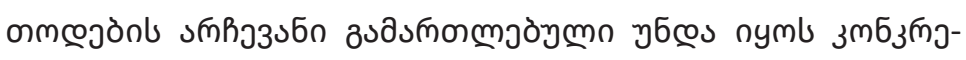

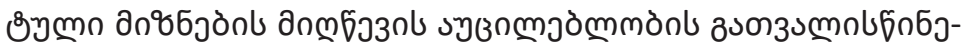
ònon.

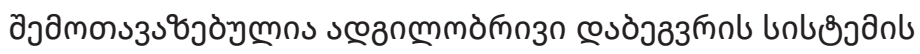

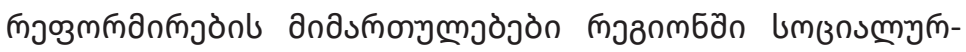

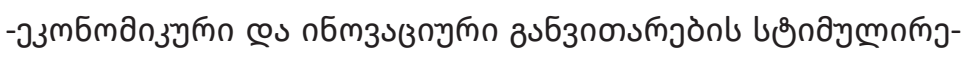

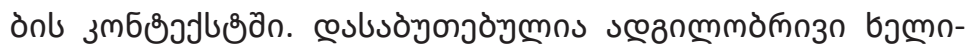

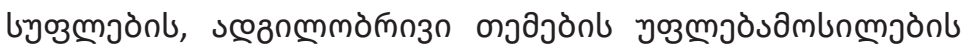

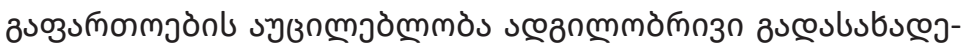

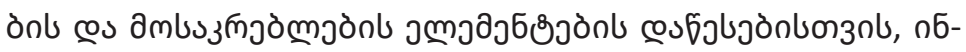

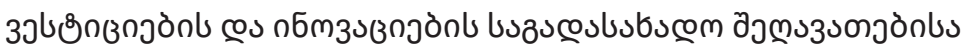

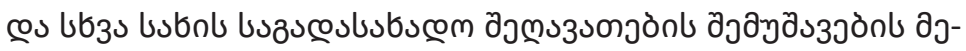

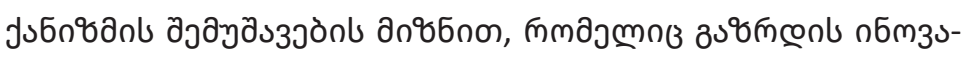

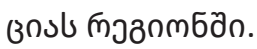

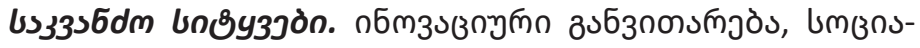

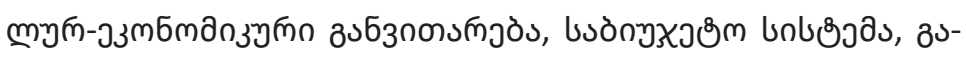

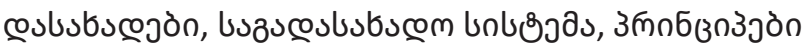




\section{INTRODUCTION.}

The low innovative activity of Ukrainian enterprises is due to various reasons, among which are the following: the orientation of the economy to invest in the development of production, rather than to intensify innovation; lack of developed innovation infrastructure; focus on the import of high-tech equipment to the detriment of domestic developments; insufficient attention to the development of own scientific and technical potential; lack of qualified management of innovation processes aimed at improving product quality, gaining competitive advantages; imperfection of instruments of legal regulation of innovation, and especially in the field of protection of intellectual property rights [10].

Innovation and innovation-oriented model of the region's development should become a key element in increasing its competitiveness and financial self-sufficiency. But innovation requires a large amount of investment resources from different sources of funding. Statistics show that over the past twenty years, the own funds of enterprises were a priority and ranged from $60.6 \%$ (2008) to $97.2 \%$ (2015) in the total cost of financing the innovative activities of industrial enterprises, public funds budget - from $0.3 \%$ (2013) to $5.2 \%$ (2018), funds of non-resident investors - from $30.0 \%$ (2010) to $0.1 \%$ (2016), funds from other sources - from $45.6 \%$ (2011) to $2.0 \%$ (2015).

Table 1 - Sources of financing of innovative activity of Ukraine's industrial enterprises

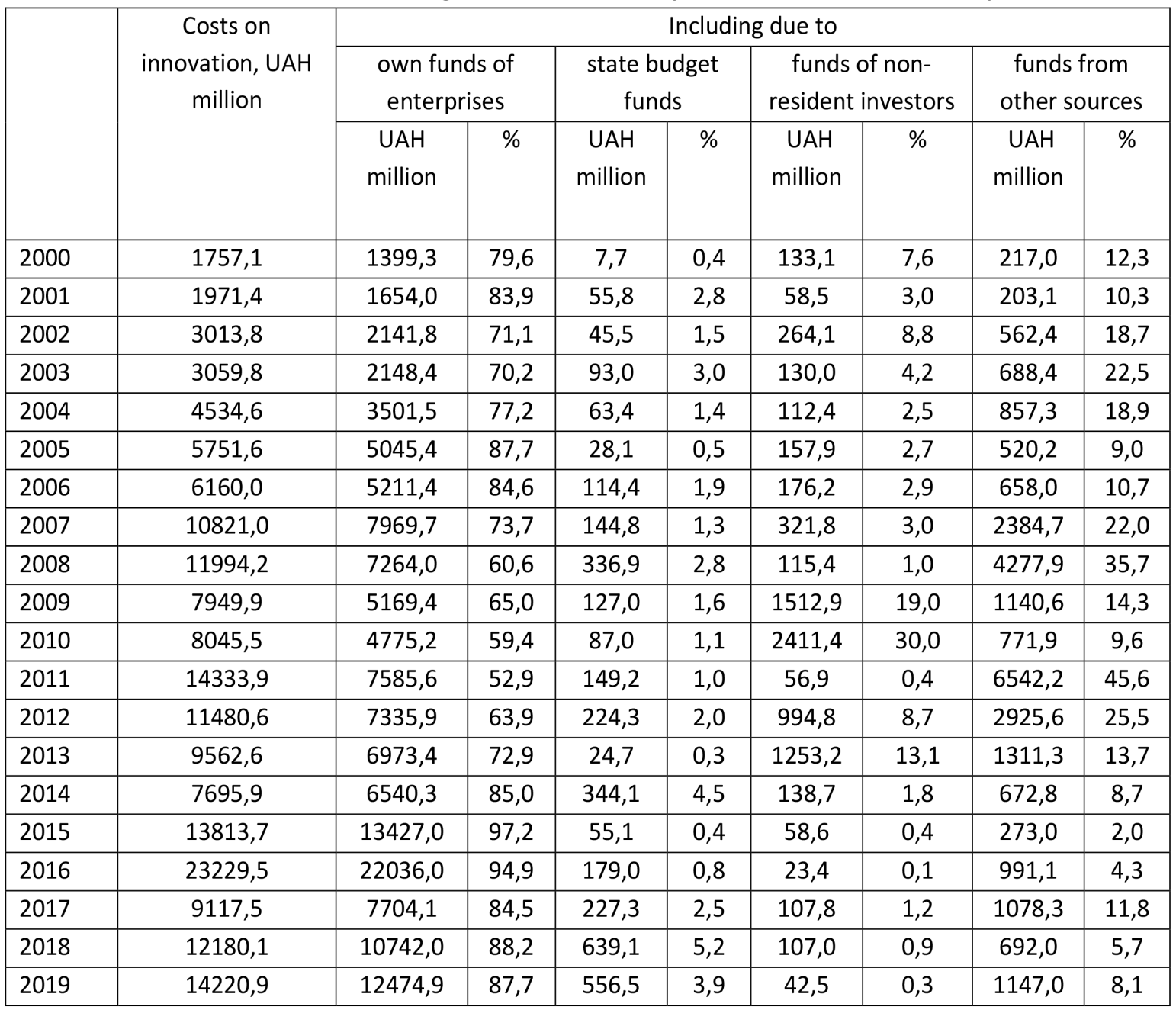

Source: compiled by the authors using [8] 
The main source of financing innovations at industrial enterprises in 2019 remains the own funds of enterprises - UAH 12,474.9 million. (or $87.7 \%$ of the total funding for innovation). The state budget received 6 enterprises, the total amount of which amounted to UAH 556.5 million. (3.9\%), the amount of local budgets amounted to UAH 109.9 million. (0.8\%), resident investors invested UAH 72.3 million. (0.5\%), funds of foreign investors were received by 3 enterprises in the amount of UAH 42.5 million. (0.3\%), the amount of funds from other sources amounted to UAH 1,147.0 million. (6.8\%), including loans - UAH 853.2 million. (6\%) [15, p. 77; 15, p. 21].

Thus, the state practically does not directly finance the innovation activities of enterprises, but it is possible and appropriate to use indirect methods of financing innovations, which are embodied in budgetary and tax policies, which require clear regulation of the relevant principles.

At the same time, the development of scientific and practical recommendations should be based on a clear definition of the theoretical foundations of support for innovation, certain initial ideas that underlie the budget and tax system, ie the main principles of their formation. Thorough research of the principles of the budget system and budget policy and the principles of organization of tax relations in Ukraine with an emphasis on the evolution of their formation and scientific views are presented in $[4 ; 13]$. But research that would contain a critical analysis of the principles of formation of the budget and tax system in terms of the priority of supporting innovative development is not enough, which determined the purpose of this work.

The purpose of this article is to study the current practice of taking into account the principles of building the budget and tax systems of Ukraine the goals of socio-economic and, first of all, innovative development and substantiation of approaches to its improvement.

Discussion and results. Analysis of the principles of the budget system of Ukraine.

The budget system of Ukraine is based on the following principles (Table 2), which are defined in the Budget Code of Ukraine [6].

Among them, in the principle of efficiency and effectiveness, it is declared that in drawing up and executing budgets, all participants in the budget process should strive to achieve the goals planned on the basis of the national system of values and tasks of innovative economic development. Another principle enshrined in the mechanism for providing subventions for the implementation of investment projects is based on the following basic principles. Among the declared principles (the principle of objectivity and openness; the principle of unity; the principle of balanced development; the principle of targeted use of funds), the principle of unity implies that the distribution of funds should ensure the implementation of national values and tasks of innovative development regions of the country.

\section{Budget principles in European legislation.}

Financial Regulation applicable to the general budget of the European Union [9] states that the budget shall be established and implemented in accordance with the principles of Unity, budget accuracy, annuality, equilibrium, unit of account, universality, specification, sound financial management and transperancy. Principle of sound financial management requires consideration of such three sub-principles:

1) the principle of economy which requires that the resources used by the Union institution concerned in the pursuit of its activities shall be made available in due time, in appropriate quantity and quality, and at the best price;

2) the principle of efficiency which concerns the best relationship between the resources 
Table 2 - Characteristics of the principles of the budget system of Ukraine, defined in the Budget Code of Ukraine

\begin{tabular}{|c|c|}
\hline Principle & Content \\
\hline $\begin{array}{l}\text { The principle of unity of the } \\
\text { budget system of Ukraine }\end{array}$ & $\begin{array}{l}\text { The unity of the budget system of Ukraine is ensured by a single legal } \\
\text { framework, a single monetary system, a single regulation of budgetary } \\
\text { relations, a single budget classification, the unity of the order of budget } \\
\text { execution and accounting and reporting. }\end{array}$ \\
\hline The principle of balance & $\begin{array}{l}\text { The authority to implement budget expenditures should correspond to the } \\
\text { amount of budget revenues for the relevant budget period. }\end{array}$ \\
\hline $\begin{array}{l}\text { The principle } \\
\text { independence }\end{array}$ & $\begin{array}{l}\text { The state budget of Ukraine and local budgets are independent. The state is } \\
\text { not responsible for the budget obligations of local governments at the expense } \\
\text { of the state budget. Local governments at the expense of the respective local } \\
\text { budgets are not responsible for each other's budgetary obligations, as well as } \\
\text { for the state's budgetary obligations. The independence of budgets is ensured } \\
\text { by assigning them appropriate sources of budget revenues, the right of } \\
\text { relevant state authorities and local governments to determine the use of } \\
\text { budget funds in accordance with Ukrainian legislation, the right of relevant } \\
\text { local councils to consider and approve relevant local budgets. }\end{array}$ \\
\hline $\begin{array}{l}\text { The principle } \\
\text { completeness }\end{array}$ & $\begin{array}{l}\text { The budgets shall include all budget revenues and budget expenditures carried } \\
\text { out in accordance with the regulations of public authorities, local governments. }\end{array}$ \\
\hline The principle of validity & $\begin{array}{l}\text { The budget is formed on realistic macro indicators of economic and social } \\
\text { development of Ukraine and calculations of budget revenues and budget } \\
\text { expenditures, which are carried out in accordance with the approved methods } \\
\text { and rules. }\end{array}$ \\
\hline $\begin{array}{l}\text { The principle of efficiency } \\
\text { and effectiveness }\end{array}$ & $\begin{array}{l}\text { When drawing up and executing budgets, all participants in the budget process } \\
\text { should strive to achieve the goals planned on the basis of the national system } \\
\text { of values and tasks of innovative economic development, by ensuring quality } \\
\text { public services while attracting a minimum amount of budget funds and } \\
\text { achieving maximum results. }\end{array}$ \\
\hline The principle of subsidiarity & $\begin{array}{l}\text { The distribution of types of expenditures between the state budget and local } \\
\text { budgets, as well as between local budgets is based on the need to bring the } \\
\text { provision of public services as close as possible to their direct consumer. }\end{array}$ \\
\hline $\begin{array}{l}\text { The principle of targeted } \\
\text { use of budget funds }\end{array}$ & $\begin{array}{l}\text { Budget funds are used only for the purposes defined by budget allocations and } \\
\text { budget allocations. }\end{array}$ \\
\hline $\begin{array}{l}\text { The principle of justice and } \\
\text { impartiality }\end{array}$ & $\begin{array}{l}\text { Ukraine's budget system is based on the principles of fair and impartial } \\
\text { distribution of public wealth between citizens and territorial communities. }\end{array}$ \\
\hline $\begin{array}{l}\text { The principle of publicity } \\
\text { and transparency }\end{array}$ & $\begin{array}{l}\text { Informing the public on budget policy, drafting, consideration, approval, } \\
\text { implementation of the state budget and local budgets, as well as control over } \\
\text { the implementation of the state budget and local budgets. }\end{array}$ \\
\hline
\end{tabular}

Source: compiled by the authors using [6]

employed, the activities undertaken and the achievement of objectives;

3) the principle of effectiveness which concerns the extent to which the objectives pursued are achieved through the activities undertaken.
Thus, the emphasis is on the general rules of management, rather than on the specific requirements of economic development.

Analysis of the principles of tax legislation of Ukraine. 
In the Tax Code of Ukraine [14] innovative development, innovations, innovative activity, even as terms, are not mentioned at all. Thus, the Tax Code defines the following principles of taxation (Table 3).

Among them there is no mention of the

Table 3 - Characteristics of the principles of tax legislation of Ukraine

\begin{tabular}{|c|c|}
\hline Principle & Content \\
\hline Generality of taxation & $\begin{array}{l}\text { Each person is obliged to pay the taxes and fees established by this Code, } \\
\text { the laws on customs matters, the payer of which he is in accordance with } \\
\text { the provisions of this Code. }\end{array}$ \\
\hline $\begin{array}{l}\text { Equality of all taxpayers before } \\
\text { the law, prevention of any } \\
\text { manifestations of } \\
\text { discrimination; }\end{array}$ & $\begin{array}{l}\text { Ensuring equal treatment of all taxpayers regardless of social, racial, } \\
\text { national, religious affiliation, form of ownership of a legal entity, } \\
\text { citizenship of an individual, place of origin of capital. }\end{array}$ \\
\hline Inevitability & $\begin{array}{l}\text { Inevitability of liability under the law in case of violation of tax } \\
\text { legislation. }\end{array}$ \\
\hline $\begin{array}{l}\text { Presumption of legality of } \\
\text { taxpayer's decisions }\end{array}$ & $\begin{array}{l}\text { Presumption of legality of taxpayer's decisions if the norm of a law or } \\
\text { other normative legal act issued on the basis of the law, or if the norms } \\
\text { of different laws or different normative legal acts presuppose ambiguous } \\
\text { (multiple) interpretation of rights and obligations of taxpayers or } \\
\text { controlling bodies, as a result of which there is an opportunity to make a } \\
\text { decision in favor of both the taxpayer and the supervisory authority. }\end{array}$ \\
\hline Fiscal sufficiency & $\begin{array}{l}\text { Establishment of taxes and fees taking into account the need to achieve } \\
\text { a balance of budget expenditures with its revenues }\end{array}$ \\
\hline Social justice & $\begin{array}{l}\text { Establishment of taxes and fees in accordance with the solvency of } \\
\text { taxpayers. }\end{array}$ \\
\hline Cost-effectiveness of taxation & $\begin{array}{l}\text { Establishment of taxes and fees, the amount of revenues from the } \\
\text { payment of which to the budget significantly exceeds the costs of their } \\
\text { administration. }\end{array}$ \\
\hline Tax neutrality & $\begin{array}{l}\text { Establish taxes and fees in a way that does not increase or decrease the } \\
\text { competitiveness of the taxpayer. }\end{array}$ \\
\hline Stability & $\begin{array}{l}\text { Changes to any elements of taxes and fees may not be made later than } \\
\text { six months before the beginning of the new budget period in which the } \\
\text { new rules and rates will apply. Taxes and fees, their rates, as well as tax } \\
\text { benefits may not change during the budget year. }\end{array}$ \\
\hline $\begin{array}{l}\text { Uniformity and convenience of } \\
\text { payment }\end{array}$ & $\begin{array}{l}\text { Establishing deadlines for the payment of taxes and fees, based on the } \\
\text { need to ensure timely receipt of funds in the budgets for the } \\
\text { implementation of budget expenditures and the convenience of their } \\
\text { payment by taxpayers. }\end{array}$ \\
\hline $\begin{array}{l}\text { The only approach to setting taxes } \\
\text { and fees. }\end{array}$ & Definition at the legislative level of all mandatory elements of the tax. \\
\hline
\end{tabular}

Source: compiled by the authors using [14]

need to ensure socio-economic and innovative development, and the principle of incentives.

The substantive analysis of the principles shows that they are focused, first, on the protection of taxpayers: the lack of opportunity to increase or decrease the competitiveness of the taxpayer (the principle of tax neutrality), setting taxes according to the solvency of the taxpayer 
(social justice), ensuring the same approach ( equality of all taxpayers), presumption of legality of taxpayer's decisions, if the rules provide for ambiguous interpretation of the rights and obligations of taxpayers or regulatory authorities), prevention of changes in rules and rates during the budget year (stability), ease of payment. Secondly, the basic principles of tax legislation take into account the interests of the budget system as a whole, namely: mandatory payment (inevitability of liability), balanced budget (fiscal adequacy), comparability of tax revenues with the costs of their administration (cost-effectiveness of taxation), timely receipt of funds in the budget for budget expenditures (uniformity and ease of payment).

Ukraine should generally provide financial support and tax incentives for innovative development at the state and regional levels, but the question arises in the choice of forms and methods of such incentives, taking into account the need to achieve specific goals. The Tax Code proposes the following grounds for granting tax benefits - features that characterize a particular group of taxpayers, their type of activity, the object of taxation or the nature and social significance of their expenses. At the same time, there are no criteria for determining such features, although there is a wide range of ways to provide tax benefits: tax deductions (discounts), which reduces the tax base before tax and collection; reduction of tax liability after tax and collection; setting a reduced tax rate and fee; exemption from tax and collection. Therefore, for such incentives, it is advisable to address the issue of developing a mechanism for investment and innovation tax credits and other types of tax benefits that would contribute to the intensification of innovative development.

World Tax Code: history and main provisions.

In the context of considering the problem of assessing the role of the tax system to ensure socio-economic and innovative development, we should pay attention to such an interesting stage in the development of world systems and the world economy as the development of the World Tax Code (BWTC) [3]. Considering the issues of globalization and integration of socio-economic systems, the problems of taxation are raised in different contexts, in particular, double taxation, international taxation, offshore zones, etc. BWTC is a project funded by Harvard University's International Tax Program that came up when Harvard University's International Tax Program Director Glenn Jenkins asked Ward M. Hussey and Donald S. Lubick to describe the results of the great work of preparing the Republican Tax Code. Tax Code was developed under the auspices of the Harvard Institute for International Development, the International Tax Program, with funding from the United Nations Economic Development Program.

The aim was to create an example of a system of laws necessary for the formation of an effective and efficient tax system, to provide specialists in reforming countries with a certain structural scheme and a list of what is needed (or not needed) to create the foundations of the tax system. The first, the so-called "Preliminary Edition» of the World Tax Code, was published in 1992, and in 1996 the 1996 Edition was published.

The BWTC contains several general principles or assumptions or principles for building tax systems. The first principle provides for the need to summarize all laws related to taxation in a single document, so that the needs for tax revenues can be assessed from a single general point of view. Simplicity, clarity and comprehensibility are assumed to be desirable objectives of the legislation. The second principle assumes that the economy will develop best if it becomes an efficient producer in the world economy. 
Therefore, it is considered that it is not in the country's interest to adopt protectionist taxation systems in which domestic capital is preferred to foreign investment, or in which certain sectors of the economy are given privileges through temporary tax exemptions or other tax benefits. The third principle: granting tax preferences is less effective than paying direct subsidies, as tax benefits are difficult to control. The BWTC rejects the effectiveness of benefits, exemptions, temporary exemptions («tax holidays») and other special preferences and agreements. The fourth principle is that, given the specifics of the economies of developing countries, the bulk of income should be generated by indirect taxes (duties, VAT and excise duties) and corporate income tax. Personal income tax and property taxes should not play a significant role. With such a tax structure, the administrative costs per unit of taxes collected will be lower than with income taxation. However, the BWTC emphasizes that many of the former socialist countries, however, have retained a high wage tax or a differentiated broad coverage tax on wages to finance social benefits. The fifth principle provides for the integration into a single income tax of all taxes levied on all types of income without the need to file a tax return. It is worth noting the second and third principles, which are useful in the context of stimulating socio-economic development and innovation.

BWTC is also based on the assumption that the development and writing of laws is only a prelude to the main thing in tax reform - the development of an effective administration system, because the presence of an honest and highly competent tax administration is an absolute necessity. In addition to the general principles, the Code includes four sections on the number of basic taxes that are recommended for introduction in market economies in developing countries: section I - income tax; section II - VAT; section III - excise taxes; section IV - real estate tax. A separate section (Section $V$ ) reveals the principles of organization of tax administration.

It should be noted that BWTC is hardly studied by domestic scientists, although its principles are relevant and should be critically analyzed in the context of the need to increase the efficiency of the domestic tax system and ensure socioeconomic and innovative development.

The use of budgetary and tax instruments to stimulate innovative development.

Given the limited and insufficient budgetary resources to finance the transition of the country's economy to an innovative model of development, the leading role should be played by the tax mechanism to stimulate innovation, along with incentive organizational measures [12]. Tax preferences can be additional infusions that can help businesses in their innovation. In particular, attention is focused on the need to introduce a system of investment and innovation tax credits as an effective tool to stimulate business activity [11]. It is emphasized that different tax preferences or their combinations are used to stimulate innovation in different countries, namely: the provision of research and investment tax credit; "Tax holidays» for several years on the profits from the implementation of innovative projects; preferential taxation of dividends of legal entities and individuals received on shares of innovative organizations; reduction of income tax rates for commissioned and joint research and development work; connection of granting of privileges taking into account priority of the executed projects; preferential taxation of profits resulting from the use of patents, licenses and other intangible assets that are part of intellectual property; reduction of taxable income in the amount of the cost of devices and equipment that are transferred to higher education institutions, research and other 
innovative organizations; deductions from taxable income of contributions to charitable foundations whose activities are related to the financing of innovations; crediting part of the profit of the innovation organization to special accounts with subsequent preferential taxation in the case of use for innovation purposes [1].

But this position has two drawbacks. First, in this case, taxpayers who apply a simplified system of taxation in the form of payment of a single tax actually remain outside the sphere of influence. Secondly, local governments are deprived of leverage through the application of local taxes and fees, which include a single tax, in particular. Therefore, the system of local taxation should not only meet the needs of local budgets in the receipt of funds, but also take into account the need to stimulate innovation activity of economic entities in the region. Accordingly, the problems of ensuring the effectiveness of local taxation and, first of all, their use as a lever to intensify innovation and investment activities of economic entities in the region, proclaiming a strategic course of public policy towards harmonization with European values of territorial self-government and budget decentralization.

According to the Tax Code of Ukraine [14], local taxes include two taxes and two fees: property tax (consists of real estate tax, other than land, transport tax, land fees); single tax; fee for parking spaces for vehicles; tourist tax.

The effectiveness of local taxation should also be determined on the basis of tax principles. There is no incentive principle among these principles, but it is indisputable that taxes in general and local taxes and fees in particular as fiscal instruments should promote stimulation and activation of economic activity.

This thesis is supported by the justification of the importance of taxes and fees to stimulate innovation [12], which is clarified taking into account the nature of local taxes and fees: provide an opportunity to cover all actors in innovation and thus ensure the necessary scale of innovation in the region; do not distort competition because they are not direct support to specific businesses; reduce the level of dependence on the budget process and covert lobbying for the choice of a particular project; reduce the costs of innovation entities, encourage them to take the risk of innovation; provide an opportunity to differentiate the subjects of innovation (applying a different set of benefits and their rates) depending on the priorities set by local governments, the stage of the life cycle of innovation, etc.

When reforming the local taxation system in the context of stimulating innovation activity of enterprises in the region, it is advisable to consider the use of tax incentives such as tax rebates, tax holidays, the use of differentiated rates or their reduction, the introduction of tax investment credit. It is the expediency of introducing the latter tool and the limits of its application are actively discussed in the economic literature.

Among the main problems of local taxation in the context of the need to stimulate innovation, it is worth noting the lack of the right of local governments to establish their own tax preferences in their territory. At present, local governments are deprived of the right to influence the elements of local taxes, which narrows the potential of local taxation, especially in the field of stimulating innovation activity of economic entities in the region in order to strengthen innovation and investment potential of the region. Local governments are objectively forced to increase the effectiveness of local taxes and fees as regulatory tools by expanding the number of their taxpayers and increasing the object of taxation, which is achieved mainly by improving the efficiency of administration of these taxes and fees. 
Proposals to expand the powers of local governments are presented in the works of domestic scholars, but they relate only to the single tax of group IV [5; 7]. Therefore, we consider it appropriate to consider the issue of expanding the powers of local governments in relation to other local taxes and fees paid by both those taxpayers who apply the simplified taxation system and those who are in the general taxation system.

The lack of local governments the opportunity to influence the determination of benefits and rates of local taxes and fees in order to intensify innovation does not contribute to increasing the competitiveness and investment attractiveness of regions. Ukraine should provide tax incentives at the state and regional levels. To do this, it is necessary to address, firstly, the expansion of powers of local governments, local authorities and local communities to establish elements of local taxes and fees, and secondly, the development of a mechanism for investment and innovation tax credits and other tax benefits that would promote intensification of innovative activity in the region.

Application of tax and budgetary instruments in the conditions of COVID-19.

It should be noted that such principles of incentives and protection have become relevant in modern conditions and are clearly illustrated by the situation with measures to support small and medium enterprises in terms of Covid-19. In Ukraine, they included the following measures: a moratorium on tax audits, temporary abolition of fines, exemption from certain local taxes and fees, change of their rates and objects of taxation by decision of local governments, deferral of registrars of settlement operations, partial repayment of taxpayers' tax debt taxes, exemption from taxes and fees of natural persons-entrepreneurs of the I group. It should be noted that a review of other countries' measures to support small and medium-sized enterprises shows that countries are also following a path of largely direct budget support.

Thus, the results of the study show that countries use such groups of fiscal measures [2]: immediate fiscal impulse, deferrals, other liquidity provisions and guarantees. Immediate fiscal impulse include additional government spending (such as medical resources, keeping people employed, subsidizing SMEs, public investment) and foregone revenues (such as the cancellation of certain taxes and social security contributions). These types of measures immediately lead to deterioration of the budget balance without any direct compensation later. The application of such measures as deferrals has certain features. Several countries have decided to defer certain payments, including taxes and social security contributions, which in principle should be paid back later. These measures improve the liquidity positions of individuals and companies but do not cancel their obligations. A few countries have also deferred the servicing of loans or the payment of utility bills, which are also important tools in improving the liquidity positions of those impacted and hence we include them. Other liquidity provisions and guarantees include export guarantees, liquidity assistance, and credit lines through national development banks. Some of these measures improve the liquidity position of the private sector, but unlike deferrals which are automatic and generally apply to the target groups, credit lines require action from the impacted companies. At the same time, there is a significant differentiation of these measures in terms of volumes and percentages to GDP and tax benefits do not play a significant role. Even if these measures are considered in the context of social justice, the protection of taxpayers should not be the ultimate goal of their application, it is important to further stimulate economic and innovative development, which should be reflected in the principles of taxation. 


\section{CONCLUSIONS}

At the same time, the stimulation of economic development in general and innovation in particular should take place on the basis of a properly constructed institutional system, which should function on the basis of certain principles. But taking into account the goals of socio-economic and innovative development is not properly reflected in the principles of both the budget system of Ukraine and the principles of the tax system (basic principles of tax legislation), although it is undeniable that direct and indirect state financial support and taxes as fiscal instruments should help stimulate economic development, stimulate and intensify innovation.

It is substantiated that Ukraine should provide general financial support and tax incentives for innovative development at the state and regional levels, but the question arises in the choice of forms and methods of such incentives, taking into account the need to achieve specific goals. A study of the practice of creating a global tax code showed that two of the five principles underlying it were to stimulate socio-economic development and innovation: the development of an efficient producer without significant emphasis on protectionist tax systems and the preference for direct budget subsidies that are easier to control compared to tax benefits. Analysis of the world practice of applying measures to support small and medium enterprises in Covid-19 showed that there is a significant differentiation of these measures in terms of volume and percentage of GDP, and tax benefits do not play a significant role. It is important to further stimulate economic and innovative development and this should be reflected in the principles of taxation and budget policy.

Accordingly, the combination of direct financial support with the introduction of investment and innovation tax credits with the possibility of their clear tax administration and control is the optimal mechanism in modern conditions. At the same time, attention should be paid not only to such national taxes as income tax and VAT, but also to the local taxation system. It is necessary to expand the powers of local governments, local authorities and local communities to establish elements of local taxes and fees, develop a mechanism for investment and innovation tax credits and other types of tax benefits that would enhance innovation in the region.

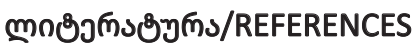

[1] Aleksieiev, I.V., \& Zhelizniak, R.I. (2012). Yevropeiskyi dosvid podatkovoho stymuliuvannia innovatsiinoi diialnosti [European experience of tax incentives for innovation]. Visnyk Natsionalnoho universytetu "Lvivska politekhnika» "Problemy ekonomiky ta upravlinnia» - Bulletin of the National University «Lviv Polytechnic» «Problems of Economics and Management», 725, 7-16 [in Ukrainian].

[2] Anderson, J., Bergamini E., Brekelmans S., Cameron A., Darvas Z., Domínguez J. M., \& et al. (2020). The fiscal response to the economic fallout from the coronavirus. www.bruegel.org. Retrieved from https://www.bruegel. org/publications/datasets/covid-national-dataset/?utm_content=buffer99084\&utm_medium=social\&utm_ source=twitter.com\&utm_campaign=buffer+(bruegel)\#portugal.

[3] Basic World Tax Code. www.taxhistory.org. Retrieved from http://www.taxhistory.org/www/bwtc.nsf/PDFs/ basica.pdf/\$file/basica.pdf.

[4] Bolduieva, O.V., \& Bolduiev, M.V. (2019). Teoretychni aspekty vyznachennia pryntsypiv orhanizatsii podatkovykh vidnosyn v Ukraini. [Theoretical aspects of determining the principles of organization of tax relations in Ukraine]. Infrastruktura rynku - Market infrastructure, 30, 385-391. 
[5] Bosenko, A.v. (2016). Orhanizatsiino-ekonomichnyi mekhanizm upravlinnia opodatkuvanniam silskohospodarskykh tovarovyrobnykiv $v$ umovakh pohlyblennia intehratsiinykh protsesiv [Organizational and economic mechanism of taxation management of agricultural producers in the conditions of deepening integration processes]. Candidate's thesis. Kirovohrad [in Ukrainian].

[6] Byudzhetnyy kodeks Ukrayiny [Budget Code of Ukraine]. zakon.rada.gov.ua. Retrieved from https://zakon.rada. gov.ua/laws/show/2456-17 [in Ukrainian].

[7] Davydov, H.M., Shalimova, N.S., Lysenko, A.M., \& Mahopets, O.A. (2017). Opodatkuvannia ta derzhavna pidtrymka silskohospodarskykh tovarovyrobnykiv: rehionalni priorytety ta yevrointehratsiini protsesy : monohrafiia [Taxation and state support of agricultural producers: regional priorities and European integration processes: monograph]. Kropyvnytskyi : FO-P Aleksandrova M. V.

[8] Dzherela finansuvannia innovatsiinoi diialnosti promyslovykh pidpryiemstv [Sources of financing of innovative activity of industrial enterprises]. ukrstat.gov.ua. Retrieved from http://www.ukrstat.gov.ua/operativ/ operativ2020/ni/dj_fin_igpp/dj_fin_idpp_u.htm [in Ukrainian].

[9] Financial Regulation applicable to the general budget of the Union. July 2018. European Comission. op.europa. eu. Retrived from https://op.europa.eu/en/publication-detail/-/publication/e9488da5-d66f-11e8-942401aa75ed71a1/language-en

[10] Kostiuchenko, V.M. (2010). Dzherela finansuvannia innovatsiinoho rozvytku subiektiv pidpryiemnytstva v Ukraini: pravovyi aspekt [Sources of financing the innovative development of business entities in Ukraine: the legal aspect]. Problemy teorii ta metodolohii bukhhalterskoho obliku, kontroliu i analizu. Mizhnarodnyi zbirnyk naukovykh prats - Problems of theory and methodology of accounting, control and analysis. International collection of scientific works, 2 (17), 161-167.

[11] Melnyk, M. (2011). Napriamy pidvyshchennia podatkovoho potentsialu stymuliuvannia dilovoi aktyvnosti $\checkmark$ Ukraini [Directions for increasing the tax potential to stimulate business activity in Ukraine]. Ekonomist Economist, 5, 28-32.

[12] Moldovan 0.0., Yehorova 0.0. (2013). Shchodo vdoskonalennia biudzhetno-podatkovykh instrumentiv stymuliuvannia innovatsiinoi diialnosti v Ukraini [Regarding the improvement of budget and tax instruments to stimulate innovation in Ukraine]. niss.gov.ua. Retrieved from http://www.niss.gov.ua/articles/1104/

[13] Myskin, Yu.V., Myskina, O.O., \& Shevchuk S.V. (2018). Pryntsypy formuvannia fiskalno-rehuliatornoho potentsialu biudzhetnoi polityky Ukrainy [Principles of formation of fiscal and regulatory potential of budget policy of Ukraine]. Naukovyi visnyk Uzhhorodskoho natsionalnoho universytetu. Seriia : Mizhnarodni ekonomichni vidnosyny ta svitove hospodarstvo - Scientific Bulletin of Uzhhorod National University. Series: International Economic Relations and the World Economy, 20, 2, 119-122.

[14] Podatkovyi kodeks Ukrainy [Tax Code of Ukraine]. zakon2.rada.gov.ua. Retrieved from http://zakon2.rada.gov. ua/laws/show/2755-17.

[15] Pysarenko, T.V., Kvasha, T.K., Rozhkova L.V., \& Kovalenko O.V. (2020). Innovatsiina diialnist v Ukraini u 2019 rotsi: naukovo-analitychna dopovid [Innovative activity in Ukraine in 2019: scientific and analytical report]. Kyiv: UkrINTEI 